\title{
Lånere og gæster i Det kongelige Biblioteks katalogværelse i årene ca. $1955-80$
}

[fortsat fra forrige nr.]

af fhv. forskningsbibliotekar, mag.art. Knud Bøgh

3.

Danske Afdeling var det tredie område, som det påhvilede katalogværelset at formidle forbindelse med, så at sige at være dens forkontor. Som det ses af grundplanen lå afdelingens kontor på den anden side udlånsskranken, havde samme størrelse som og var symmetrisk med katalogværelset. Den havde en dør direkte til forhal. Da den var aflåset, måtte en benytter med bud efter danske bøger rundt om det altid tilgængelige katalogværelse og der fremføre sine $\emptyset$ nsker. Helt elementært gjaldt det om at hente de nødvendige håndbøger eller - som oftest - de alfabetiske skuffer, hvorefter låneren udskrev sine rekvisitioner.

Sedlerne lå tæt i skufferne, og bibliotekaren kunne bære to ad gangen, en tredie var ikke tilrådelig, men tiest var det en enkelt for at efterlede et bestemt forfatterskab. For en stillesiddende bibliotekar var det ganske sundt at bære skuffer ind og derpå tilbage igen. Vejen gik bag udlånsskranke og derpå gennem døren i hjørnet ved den indre gård. De fleste alfabetiske skuffer stod på den ene langvæg, og de dækkede landets bogproduktion til og med 1959. Senere blev de suppleret med kartoteksskabe i mørkt træ, en række skuffer for tiden 1960-69 samt 1970 og fremad. Herinde har man valgt at dele perioden i ti-årige lag. De systematiske skuffer er inddelt efter decimalopdelingen, den som bruges på folkebibliotekerne. Talrige lånere var således forud fortrolige med dem. Det sparede tid, og biblioteket havde derved sparet mange kræfter, som ellers var medgået til planlægning af nye systemer. Det kongelige Biblioteks samlede bogbestand var således på det tidspunkt registreret i mindst fem systemer, var fem biblioteker i eet.

Afdelingens personale havde i de år ord for at være lidt partikulært og føle sig som en stat i staten. Når døren gik, rejste damerne hovederne og så 


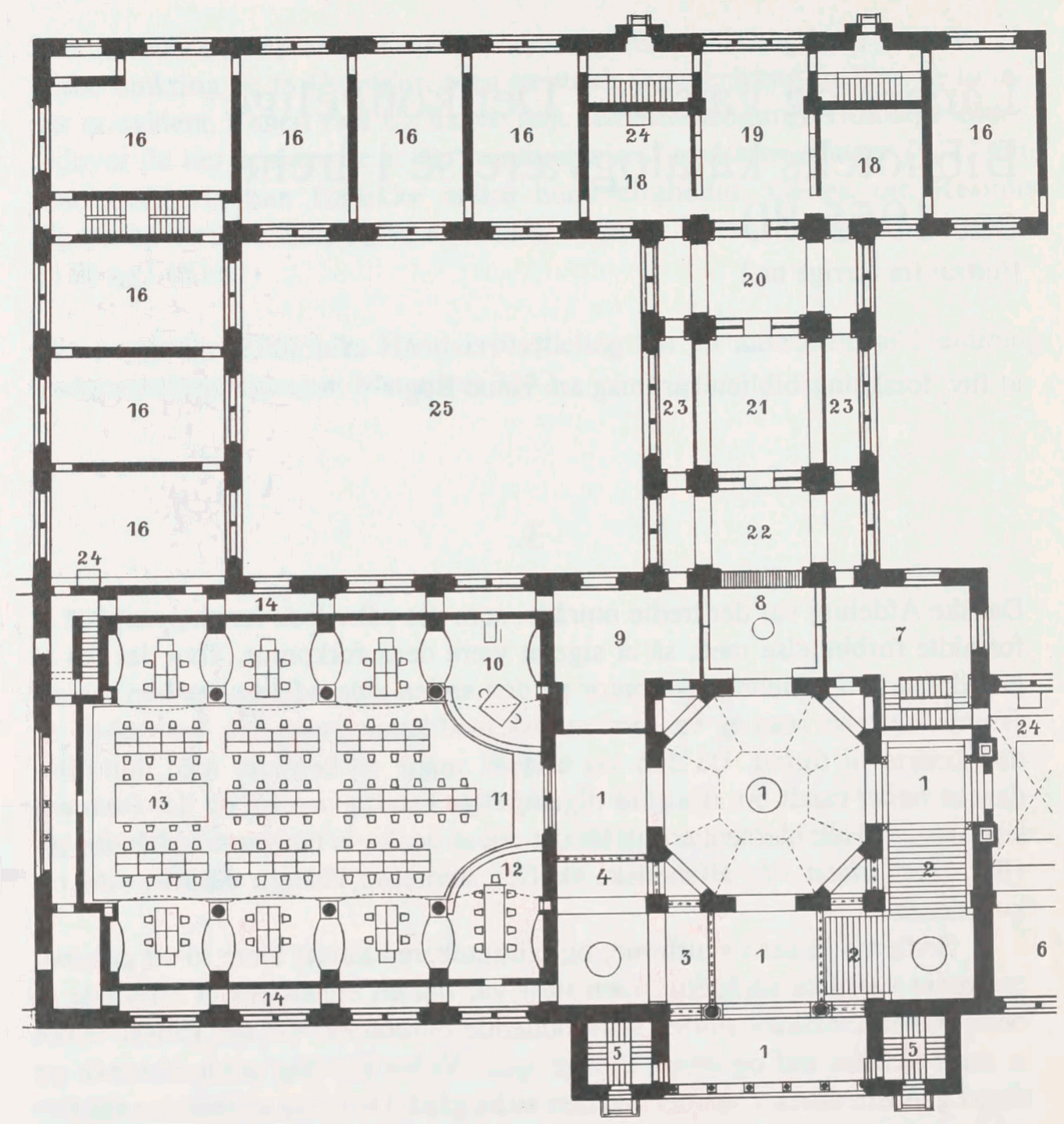

Det kongelige Biblioteks grundplan før ombygning. Til venstre Læsesal og magasiner. 7 Danske Afdelings kontor. 8 Udlån. 9 Katalogværelse. 22 var forbindelsen mellem katalogværelse og Danske Afdeling, der var placeret symmetrisk.

venligt på den indtrædende. Det var ikke frit for, at yngre ansatte vogtede sig for at stille spørgsmål i dette kontor. En gæst betroede mig en gang: de sidder der som en sluttet falanks, hvor spyddene stritter ud til alle sider som i en vognborg. Deres svar var altid kontante, hjertelige. - En låner beder om den danske oversættelse af Wells' Tidsmaskinen, i hvilken katalog kan den mon stå? - I det mindste ikke i den med maskinlære, lød det blide svar. 
Man blev klogere, til næste gang man hentede en skuffe eller viderebragte et spørgsmål, der var stillet. De blev gennem årene mangfoldige. Gennem en periode i 1970-erne noterede jeg i farten ned på lapper en del af de problemer, der blev fremført, og de hidsættes her, som de ligger i en gammel kuvert: Hvor har Aage Dons omtalt Marcel Proust? Har man gemt smudsomslagene til tidlige H. C. Andersen-udgaver? Findes der en fortegnelse over indbo solgt på auktion efter Juliane Marie; Thurahs papirer angående orglet på Børglum Kloster; da Napoleon besatte Ægypten, havde han da kendskab til de tanker, Carsten Niebuhr havde gjort sig om at grave en Suezkanal? Jeppe på Bjerget, hvor på Sjælland hørte han til? Hvordan er fremgangsmåden ved at besvare gækkebreve? I morgen formiddag skal jeg til et møde om Grønland - kunne De ikke lige give mig en liste over den juridiske litteratur, der findes med henblik på Grønland? Der blev spurgt om priser på gamle dukker; om hatte på Lolland-Falster; Drachmanns håndskrift; fundamenterne til Vestindisk Pakhus; om Toldkammerbygningen i Åbenrå; Bovrup-kartoteket; vejrhaner; fugleskræmsler; vaudevillen "Nej" på fransk; Nøddebo præstegård; Jehovas vidner; profeten Martinus; studenter fra Roskilde; Rafaels $\emptyset$; Frederik VI's elskerinde i Wien - hvor længe oppebar hun pension fra den danske statskasse?

De kunne stort set besvares med opslag i kataloger, i læsesalens håndbibliotek, ved almindelig rutine og ved at lade forespørgslen gå videre til de kyndige på Danske Kontor, eller måske til eksperter uden for huset. Mange kom med en bog under armen og spurgte, hvad den var værd i penge. Hvis man svarede: Måske $100 \mathrm{kr}$., risikerede man, at spørgeren gik op gennem Fiolstræde for at forhøre hos de handlende, hvad de ville betale. Hvis boghandlerne så svarede: $10 \mathrm{kr}$., så spørgeren bebrejdende på dem og fortalte, at nede på Det kongelige Bibliotek vurderede de bogen til $100 \mathrm{kr}$. Pinligt for alle, så derfor henviste vi spørgeren til de priser der var blevet betalt på de sidste bogauktioner. Salgslisterne med de betalte beløb står fremme, til disposition for alle, og ingen bliver snydt eller vrede på hinanden.

- Som dreng læste jeg en bog, der på omslaget havde et billede af en mand med en kniv mellem tænderne, han sad i en mast og svingede med et sort flag. Handlingen var sådan og sådan - Har I den stående? Humøret steg, når gætningerne blomstrede og måske ramte i plet, og dalede når bibliotekaren forblev komplet tom i hovedet og ikke havde kendt sin besøgelsestid. Man kunne dengang endnu ikke udnytte Mette Winges disputats Dansk Børnelitteratur 1900 - 1945 med sarligt henblik på børneromanen (1976).

Nogle rynkede på næsen ad de forespørgsler, vi til tider besvarede, og fandt, at de kunne spærre for vigtigere opgaver. Naturligvis fik de mere centrale og faglige emner fortrinsret for de perifere - ligesom et hospital har en 


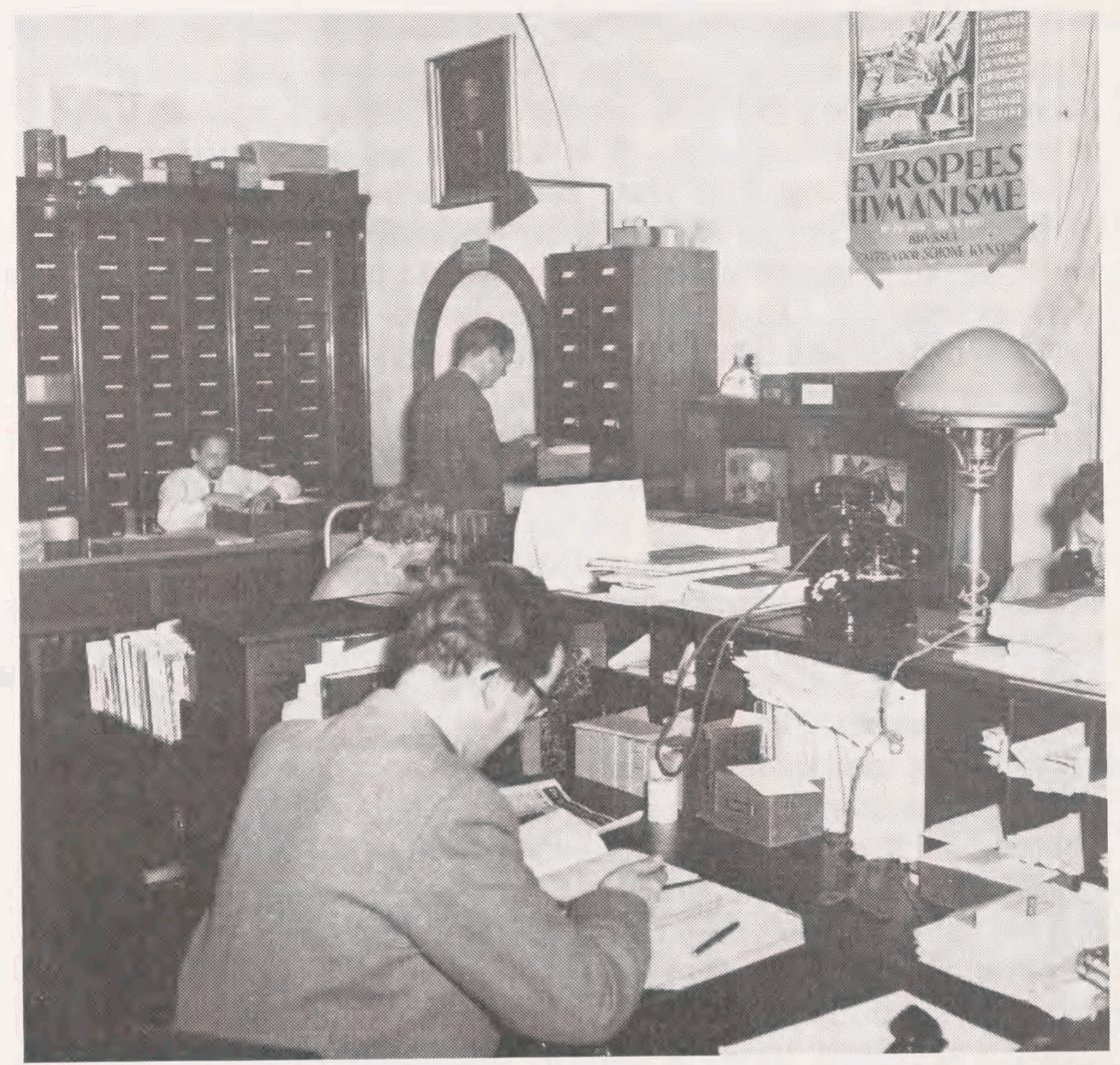

Danske Afdelings daværende kontor set mod indgangen fra Udenlandske Afdeling og Udlån. I baggrunden den alfabetiske katalog over danske og norske tryk. Dér sad en dag Halvdan Koht og granskede. I forgrunden Erik Dal.

skadestue, der tager sig af en forstuvet fod og bulne fingre uden at fors $\emptyset \mathrm{mme}$ den fundamentale gerning. Hvis man vil finde et fint ord for disse spørgere, kan man kalde dem eengangs-forskere, som også har deres ret.

Af historiske grunde omfattede Danske Afdeling samtlige gamie danske lande, Fællesmonarkiets provinser fra Elben til Nordkap. Afdelingen blev grundlagt allerede i 1780 som et Biblioteca septentrionalis. Dette historiske perspektiv medførte, at den vagthavende tit mått tænke sig godt om, når en låner ville have litteratur om Helgoland, Plön, Altona, Oldenburg, Gottorp for ikke at tale om de mennesker der var født i de egne, men havde gjort sig gældende i Stortyskland. Hebbel, Theodor Storm og Mommsen er stort set placeret fornuftigt, selv om de var født indenfor Fællesmonarkiet. Men over- 
gangen mellem disse områder, deres suverænitet i svundne tider, kan en uforberedt låner ikke vide noget om. Så var det godt at have indenfor rækkevidde en historiker, der kunne sin topografi, en der vidste hvilket land, der ejede Helgoland og hvor længe. Her var de røde kasser ligeledes til hjælp. Alle sparede kræfter, når de fik begyndt i den rigtige ende.

Så var det mere ligetil at have at gøre med Norge, hvis historie, topografi, personalhistorie og meget andet hørte til på Danske Afdeling. Forholdet er hjerteligere og indebærer ingen drilagtige grænsespørgsmål som mod syd. De store nordmænds litterære tekster står der, ligesom Håndskriftsamlingen rummer deres manuskripter i stort tal. Til en Henrik Ibsen-udstilling i forhallen var der derfra, blandt billeder og tryk, lagt ud i montrerne sjældne sager. Det lød som en fanfare, da en nordmand trådte ind ad døren til katalogværelse og på sit klingende sprog glad fortalte om sin overraskelse over, at der var så mange Ibsen-manuskripter hernede. Ikke blot de renskrifter Ibsen havde sendt til Dansk Gyldendal, havde han fundet, men oven i købet de første udkast til Peer Gynt og Brand. Gæsten præsenterede sig som Paulus Svendsen, der hævdede, at han ikke kendte historien om, hvordan Ibsen i Rom havde efterladt en gammel kuffert med kladdeme til den såkaldte episke Brand og om, hvordan den gennem Karl Larsen var reddet og endt i København. Og mest storslået: han fandt det i sin orden, at klenodiet var her og undte det $\mathrm{kgl}$. danske bibliotek dets triumf.

Ikke så få nordmænd dukkede op, fik skuffer med norske forfatterskaber bragt ud i katalogværelse eller sad til tider hjemmevant på det Danske Kontor med Norge-katalogerne. Der sad en formiddag den norske historiker Halvdan Koht, udenrigsminister 1935-41, dengang han førte en strikt neutral balancepolitik og endnu den 8 . april 1940 brugte dagen til at udarbejde en skarp protest mod engelsk mineudlægning i norske farvande, mens tyskerne var på vej sydfra. Som gammel mand skrev han Inn i Einveldet 1657-61 (1960), hvori han forsvarede Frederik III's beslutning om en krigserklæring til Carl X Gustafs Sverige, fordi den danske konge havde indset, at det svenske angreb under alle omstændigheder måtte komme. Nu så den store norske historiker den danske konges beslutning i lyset af, hvad Hitlertidens Norge havde oplevet i hans egen regeringstid. Eftersom det svenske angreb i 1600tallet var planlagt i alle detailler, betragtede Koht nu den krig som en forsvarskrig. Vi danske har hidtil beklaget 1657-krigen som hasarderet, ja tåbelig. Men her sad nu en 87 -årig nordmand, klog af skade og viis med årene, i Frederik III's bogsamling og gav dens grundlægger fuld oprejsning.

Da Norge ejer sit eget nationalbibliotek, havde Danske Afdeling ikke årsag eller pligt til at dække landets hele bogproduktion som man tilstræber med den danske. Men som gaver fik man eller købte af det bedste. Anderle- 


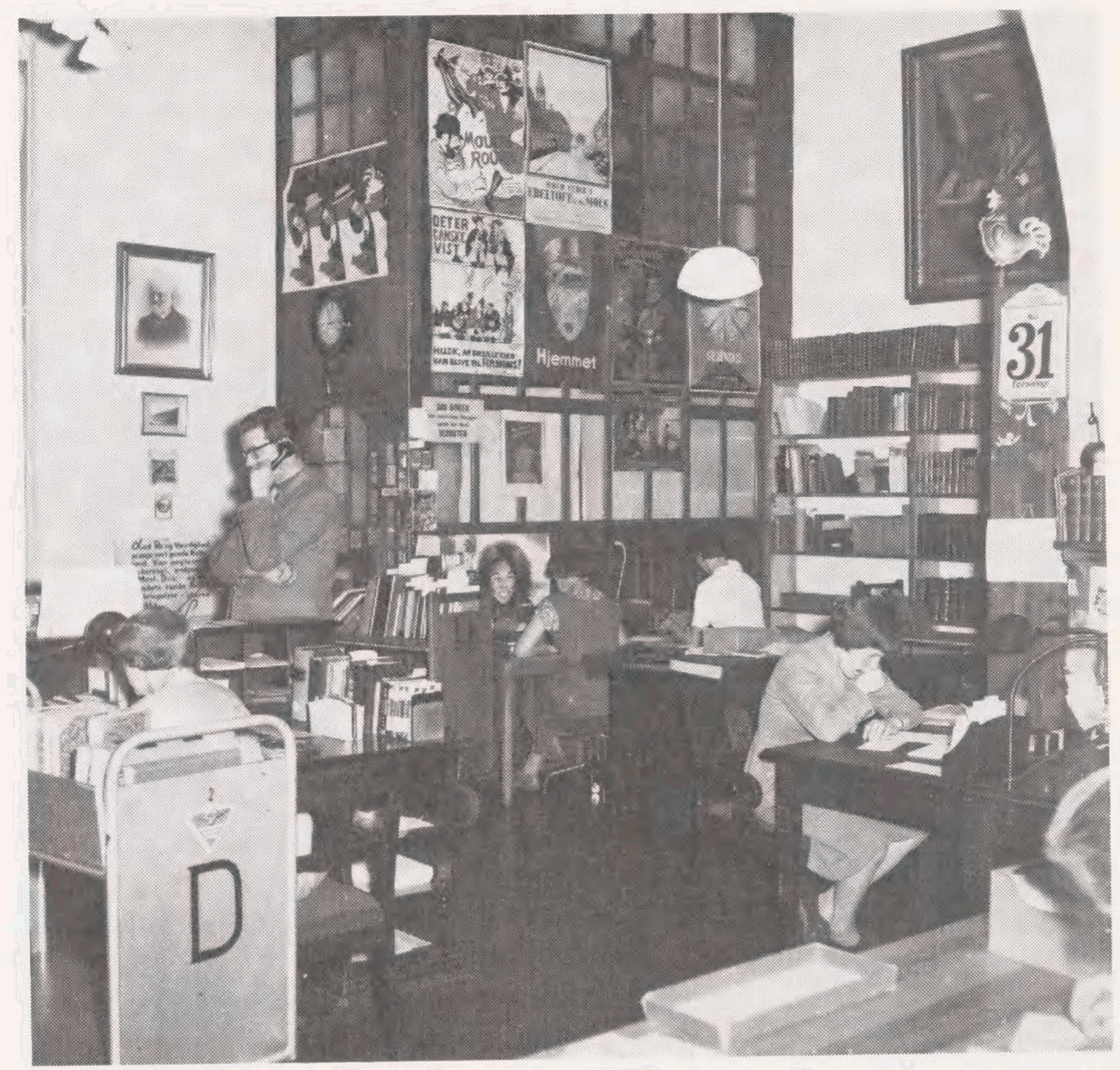

Foto fra 1956, der viser de snævre arbejdsforhold på Danske Kontor. Under uret udgangen til Danske Afdelings magasiner.

des med det, som man trykker hertillands. Gennem en længere periode kom der hver lørdag i katalogværelse en mand med rare, runde øjne og strithår og rekvirerede skuffen med Anders And, hvis alfabetiske sedler blev nøje gennemgået og gransket. Fra pligtaflevering vides, hvor vanskeligt og tidskrævende det er at få hefteskrifter af denne art fuldstændig i hus. Mange læser dem og lader det være godt med det. Denne mand var samler og gemmer. Der kom lys i hans $\varnothing j n e$, da det viste sig, at han ejede numre som manglede på nationalbiblioteket, og da han skænkede os visse dubletter, var både han og vi glade.

For et nationalbibliotek skal ligesom denne mand være samler og intet arbejde sky for gennem pligtaflevering at skaffe i hus hele den danske pro- 
duktion af bøger og tryksager, bl.a. de utallige sidestykker til Anders And. I princippet modtager man alt og gemmer så godt som alt. Når denne trykmasse organiseres godt i bibliotekets bog- og småtryksafdeling, gemmer den i sig svar på alle de forespørgsler, der kan stilles angående hvilket som helst forhold i Danmark, når blot der søges med plan og fantasi. Dækningen af et bredt materiale er anderledes tæt i dette tilfælde, end hvor det gælder bibliotekets udenlandske bogbestand, som anskaffes efter kvalitet og kun derfor. Samtlige danske bøger og tryksager vandrer år for år ind på reolerne, hvor fuldstændighed, kvantitet broderligt forenes med blivende værdier. Tegneserier har samme ret som Søren Kierkegaard eller Karen Blixen.

Morten Korch var længe ugleset og blev hånet i de litterære blade, men hans bøger indgik regelmæssigt i nationalbiblioteket og blev registreret ved siden af andre forfatterskaber. Men efter anden verdenskrig trængte nye behov igennem og fortrængte fortidens aristokratiske tendenser. Folks lekture blev nu set i lyset af marxisme, man interesserede sig for masselitteratur, for hvor store oplagene blev, hvem købte bøgerne eller læste dem? Man skrev en hel bog om Søndags-B.T.'s læsere. Dette mægtige stof for studiet af triviallitteratur havde altid ligget på bibliotekets danske afdeling, først som folkebøger og siden som kiosk-hefter i lange serier.

Nu kom det på én gang til sin ret, blev respekteret som værdig genstand for alvorlige studier. Nationalbiblioteket havde sørget for at bevare de foreteelser som længe var ilde anskrevne. Uafhængig af litterære og videnskabelige moder havde den gamle institution taget tingene til sig og var øjeblikkelig i stand til at imødekomme de nye krav. De skiftende spørgmål vedrørende den danske bogtryk-produktion, som modtages i katalogværelse, bekræftede til fulde, at et nationalbibliotek skal vise tålmod og tolerance, vente på sin tid.

[fortsættes i næste nr.] 